\title{
IMAGEN 2-2014: Proceso estiloides segmentado en un paciente con lesión medular
}

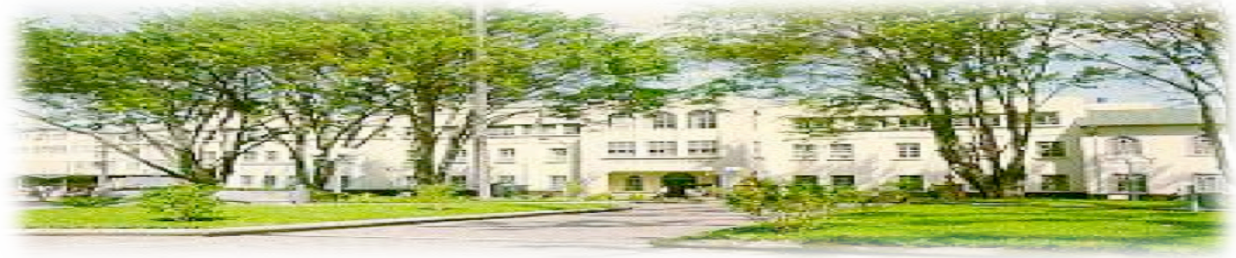

Haspital San quan de Dias. San Jasé, Casta Riua. Fundada en 1845

Recibido: $\quad 21 / 07 / 2014$

Aceptado: $\quad 20 / 08 / 2014$

Paula Vargas Gonzalez ${ }^{1}$ Manuel Wong $\mathrm{On}^{2}$

${ }^{1}$ Médica Especialista en Imágenes Médicas. Médico Asistente Centro Nacional de Rehabilitación. Correo electrónico: pauvargo@yahoo.com

${ }^{2}$ Médico Especialista en Medicina Física y Rehabilitación. Médico Asistente Centro Nacional de Rehabilitación. Correo electrónico: manuwongon@gmail.com
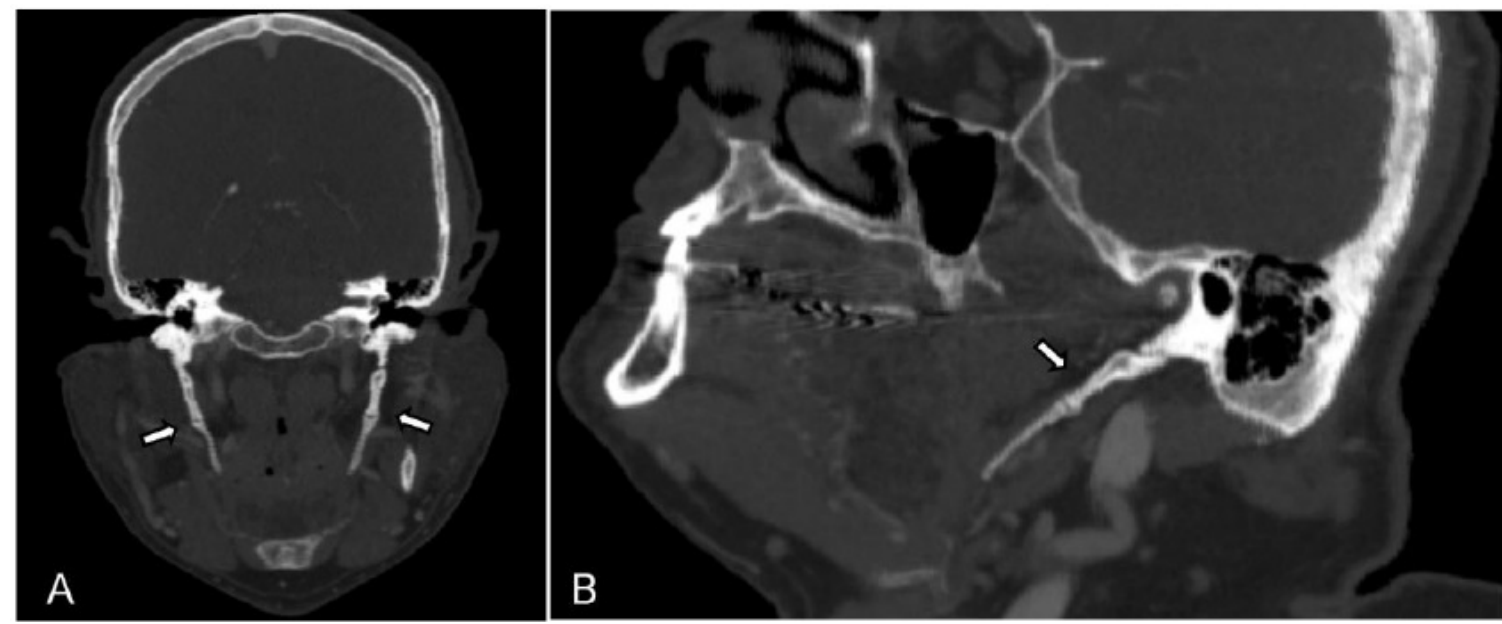

Cortes Axial A y Sagital B en el TAC donde se puede visualizar la prolongación segmentada del proceso estiloides (flechas). 


\section{RESUMEN DEL CASO.}

Paciente masculino de 53 años internado por una tetraplejia incompleta bajo C4 ASIA D secundario a un infarto medular y que en las radiografías cervicales se evidencia la presencia de prolongaciones óseas a nivel de procesos estiloideos y un TAC que corrobora el hallazgo.

\section{DISCUSIÓN}

La elongación del proceso estiloideo se clasifica $\mathrm{en}^{(1)}$ :

- Tipo 1: Elongado

- Tipo 2: Pseudoarticulado

- Tipo 3: Segmentado

Rara condición que afecta a un $4 \%$ de la población y que al asociar síntomas de compresión de pares craneales o caróticas $(4-10.3 \%)$ se conoce como Síndrome de Eagle ${ }^{(2,3)}$. Los síntomas se desarrollan generalmente después de una amigdalectomía y el tratamiento consiste en uso de analgésicos, AINES, infiltraciones con esteroides $\mathrm{y}$ en casos severos resección quirúrgica ${ }^{(4)}$.

\section{BIBLIOGRAFÍA}

1. Langlais RP Langland OE Nortjé CJ. Diagnostic Imaging of the jaws. $1^{\circ}$ Edition. Williams \& Wilkins, 1995: 620-622.

2. Eagle WW. Elongated styloid processes: report of two cases. Arch Otolaryngol. 1937;47:584-587

3. Rechtweg JS Wax MK. Eagle's syndrome: a review. Am J Otolaryngol. 1998;19:316-321.

4. Ceylan A Köybaşioğlu A Celenk F et al. Surgical treatment of elongated styloid process: experience of 61 cases. Skull Base. 2008;18(5):289-295. 